\title{
Faculty of Commerce
}

An empirical study of mutual funds performance in China

D. Chen, C. Gan, and B. Hu

Faculty of Commerce Working Paper no. 2

July 2013

ISSN: 2324-5220

ISBN: 978-0-86476-325-9 


\section{Copyright statement:}

This information may be copied or reproduced electronically and distributed to others without restriction, provided the Faculty of Commerce, Lincoln University is acknowledged as the source of information. Under no circumstances may a charge be made for this information without the express permission of the Faculty of Commerce, Lincoln University, New Zealand.

Series URL http://hdl.handle.net/10182/4745

\section{Guidelines for authors of working papers}

1 Include an abstract of not more than 250 words at the beginning of the paper.

2 Provide at least three keywords but not more than five. Keywords should not duplicate words already used in the title.

3 Calibri 12pt font, single line spacing and UK spelling are preferred.

4 Section headings should be sequentially numbered and boldfaced.

5 Tables must be sequentially numbered and titles should appear in boldface above the table. Locate tables where they logically fit and introduce them in the preceding text.

6 Figures must be sequentially numbered and titles should appear in boldface below the figure. Locate figures where they logically fit and introduce them in the preceding text.

7 Use any recognised method of referencing. Consistency is the key.

8 Endnotes, Acknowledgements, References and Appendix Tables should be presented in that order after the text.

\section{Faculty of Commerce}




\title{
An empirical study of mutual funds performance in China
}

\begin{abstract}
This study evaluates equity mutual fund performance in the Chinese mutual funds industry by employing Goetzmann and Ibbotson's (1994) method. The data set consists of all openend equity mutual funds in China and is free of survivorship bias. The research period covers January 2002 to December 2010. Equity open-end funds selected for this study are not terminated or merged into other funds before the end of 2010. The results from this study reveal that the equity mutual fund managers in China have selective ability to earn excess returns, but do not have market timing ability.
\end{abstract}

Keywords: Mutual fund performance, selective ability, market timing ability, China.

\section{About the Authors:}

David Chen is a Master Student in the Department of Accounting, Economics and Finance, Faculty of Commerce, Lincoln University, Canterbury, New Zealand. Contact email: david.chend@gmail.com

Christopher Gan is Professor of Accounting and Finance, in the Department of Accounting, Economics and Finance, Faculty of Commerce, Lincoln University, Canterbury, New Zealand. Contact email: Christopher.Gan@Lincoln.ac.nz

Baiding $\mathrm{Hu}$ is a Senior Lecturer in Economics in the Department of Accounting, Economics and Finance, Faculty of Commerce, Lincoln University, Canterbury, New Zealand. Contact email: Baiding.Hu@Lincoln.ac.nz 
The evaluation of mutual funds performance has been a topic in financial economics for a long time. Many studies have attempted to evaluate the performance based on different market, using a variety of performance measurement techniques and adjustments for risk. By investigating the portfolios' performance, the abilities of the portfolio manager to increase returns by correctly predicting the future and the abilities to minimize portfolios risk could be observed (Jensen, 1968). With the increasing importance of mutual funds in financial markets, the debate about the measurement of mutual fund performance has been an on-going issue since the 1960s.

Some researchers suggest that mutual funds can perform better than a passively managed portfolio or selected market indices, but others suggest the opposite. Sharpe (1966) and Jensen (1968) find mutual funds, in general, cannot perform better than passively managed portfolios (selected market indices). Jensen concludes that mutual funds on average and individual fund both cannot outperform the market even when the costs such as bookkeeping and research expenses are assumed free. Malkiel (1995) investigated mutual funds' performance over a relatively longer research period and makes a similar conclusion. Those results are consistent with Fama's (1970) efficient market hypothesis, which states that the success of mutual funds is due to luck not skill and, therefore, mutual funds should not be able to perform better than the market.

On the other hand, Carlson (1970) finds evidence that mutual funds can beat the market. The author partially replicates Jensen's (1968) study for 82 mutual funds' performance, and showed contrasting result. Carlson argues that Jensen's (1968) result and the evaluation of mutual funds performance will be influenced by the selection of time period and market index. Mains (1977), Chang and Lewellen (1984), and Ippolito (1989) also confirm that mutual funds earn higher returns than passively managed portfolios. Based on the previous research, the conclusions of whether mutual funds could provide better performance than the market are mixed.

This study evaluates equity mutual fund performance in the Chinese mutual funds industry by employing Goetzmann and Ibbotson's (1994) method. The data set consists of all openend equity mutual funds in China and is free of survivorship bias. The research period covers January 2002 to December 2010. Equity open-end funds selected for this study are not terminated or merged into other funds before the end of 2010. The results from this study reveal that the equity mutual fund managers in China have selective ability to earn excess returns, but do not have market timing ability.

This paper is organized as follows. Section 2 reviews existing literatures on mutual fund managers' selective ability and market timing ability. Section 3 discusses the data and research methodology. The analysis of the empirical findings is discussed in Section 4, and section 5 concludes the study. 


\section{Literature Review}

\subsection{Mutual fund managers' selective ability}

Sharpe (1966) is one of the first studies that researched on mutual fund managers' selective ability. The author calculates the reward-to-volatility ratios for mutual funds and the market index. The reward-to-volatility ratio for each mutual fund is compared with the reward-tovolatility ratio of the market (Dow Jones index). Sharpe (1966) shows that the reward-tovolatility ratios of mutual funds are lower than the ratio of Dow Jones index, which indicates mutual funds, in general, cannot perform better than the market, i.e., mutual fund managers might not have selective ability.

Jensen's (1968) study is instrumental to measure mutual fund performance using riskadjusted return. The author develops the CAPM model using a time series model to evaluate mutual fund performance. The alpha ("single-index alpha") generated from Jensen (1968) is the difference between the actual average returns of funds and the expected returns in the same portfolio by employing CAPM. According to Jensen, a zero single-index alpha represents the market portfolio buy and hold policy; a positive single-index alpha represents fund managers that have selective ability, and a negative single-index alpha indicates fund managers do not have selective ability to outperform the market. The author finds evidence that the 115 funds in the sample, on average, cannot perform better than the market during the research period, which indicates mutual fund managers, in general, do not have selective ability.

Malkiel (1995) confirms Jensen's (1968) results. The author follows Jensen's (1968) method to measure mutual fund performance from 1972 to 1991 in the U.S. market. The author used quarterly returns of equity funds to calculate the single-index alpha. The author argues that mutual funds, in general, do not produce positive excess returns for investors since the single-index alpha from 1972 to 1991 is insignificant.

Similarly, Carlson (1970) follows Jensen's (1968) method, chooses Standard \& Poor's 500 as the benchmark, and retests the results from Jensen (1968) and Sharpe (1966) using annual returns for 82 equity funds from 1948 to 1967. Carlson results contradict the studies of Jensen (1968) and Sharpe (1966) in that positive excess returns to the value of 60 basis points could be earned by mutual funds. The author argues that the conclusion of Jensen and Sharpe that mutual fund managers, in general, do not have selective ability, might be biased because of the selected time periods and the market index.

Mains (1977) argues that Jensen's (1968) method may have bias in the assumption about mutual funds' dividend yields. Jensen uses annual returns of mutual funds and assumes dividends are paid at the end of year, whereas dividends are actually paid quarterly, so the reinvestment issue has been ignored as a result. Mains used the same method as Jensen) with monthly data, and partially repeats the work of Jensen from 1955 to 1964 . The author finds that mutual funds earn a positive alpha of 9 basis points using monthly returns. Based on Mains' finding, mutual fund managers have selective ability based on positive excess returns. 
Grinblatt and Titman (1993) introduce a new measurement to analyse the performance of mutual funds without benchmarks. One quarterly and one yearly portfolios are set up corresponding to each mutual fund. The weights of the quarterly portfolio are calculated as the difference between the portfolio weights of mutual funds in the current quarter and in the previous quarter. The weights of the yearly portfolio are calculated by the portfolio weights of mutual funds at the beginning of the quarter minus the weights one year earlier. The results indicate that the average performance of the quarterly portfolio is close to zero, but the yearly portfolio has a significant positive 200 basis points, on average, per year. The authors conclude their results are consistent with Grinblatt and Titman (1989) where mutual funds, on average, gain positive excess returns and therefore mutual fund managers might have selective ability.

\subsection{Market timing}

According to Jensen (1972), estimates of single-index alpha might be biased if the systematic risk is non-stationary. To partly solve the problem of non-stationary systematic risk, the managers' selective ability and market timing should be separated. Fama (1972) and Treynor and Black (1973) argue that mutual fund managers' forecasting ability could be classified as selective and market timing ability.

Treynor and Mazuy (1966) argue that if mutual fund managers have market timing ability, they are able to anticipate whether the general stock market is going to rise or fall and then adjust the composition of portfolio accordingly. Thus mutual fund returns and market return are non-liner related. The authors introduce a quadratic timing regression to measure the market timing ability of mutual fund managers as the coefficient on the squared market excess return. The authors find only one fund of 57 open-end mutual funds had significant market timing ability.

Gallo and Swanson (1996) employ the Treynor and Mazuy (1966) market timing model to test 37 U.S.-based international mutual funds' performance from 1985 to 1993. The authors find no evidence of superior market timing ability for any fund in the sample. Gallo and Swanson's (1996) result is consistent with Gallo and Lockwood (1999) and Jiang, Yao and Yu (2007) findings, which show mutual fund managers, in general, are not able to forecast market condition in future.

Henriksson and Merton (1981) and Henriksson (1984) introduce parametric models to test market timing ability for portfolio or securities. The quadratic term in the Treynor and Mazuy (1966) model is replaced by a coefficient of the market portfolio option payoff, where the exercise price equals the risk free asset. Henriksson (1984) applied the parametric model to test market timing ability for 116 open-end mutual funds from 1968 to 1980 in the U.S. stock market, and the result indicates no evidence of market timing ability. Henriksson also finds a negative relationship between market timing and selection ability.

Chang and Lewellen (1984) follow Henriksson and Merton (1981) study to test mutual fund performance and market timing ability using monthly data for 67 funds from 1971 to 1979 in the U.S. market. Their result shows the monthly average excess return of mutual funds is close to zero if market timing is ignored and the monthly average excess return is 116 basis 
points when the market timing factor is considered. Although weak evidence of the market timing ability of mutual fund managers is found, the average mutual fund performance outperforms the market. The result confirms the positive alpha found in Alexander and Stover (1980), Veit and Cheney (1982) and Kon (1983) studies. The researchers provide little evidence that fund managers have successful market-timing ability.

\section{Method and Data}

The data for this study are obtained from China Centre for Economic Research at Beijing University (CCER) database. The CCER database provides a comprehensive coverage of the Chinese economy and capital markets' information and commits itself to be the worldleading Chinese financial information provider and analyst. ${ }^{1}$ Since the first open-end equity mutual fund was established in November 2001, this research covers the period from January 2002 to December 2010, and all open-end mutual funds are included in the sample. No mutual funds have ceased operations or merged with other mutual funds during the research period. Qualified Foreign Institutional Investors (QFII), Exchange Traded Funds (ETF), Listed Open-end Funds (LOF) and index funds are excluded from the sample.

The market index used in this study is S\&P/CITIC indices, which is the only overall market index available in China. The S\&P/CITIC indices cover both Shanghai and Shenzhen A-share markets in China (market capitalization-weighted indices) and include other factors such as non-tradable shares, dividend reinvestment, large/small capitalization, and value/growth stock classifications. ${ }^{2}$ Following Drew, Naughton and Veeraraghavan (2003), the one-year fixed deposit rate in the first month of each year is used as the risk-free rate. The fixed oneyear deposit rates were obtained from the People's Bank of China.

This study follows Morningstar's (2007) method to calculate monthly raw returns of mutual funds. Dividends are assumed to be paid and reinvested at dividend payment date for each fund. According to Mains (1977), the systematic risk coefficients can be estimated more efficiently and the bias of reinvestment issue can be reduced. Mains assumes that dividends paid by mutual funds are reinvested at the end of the month. This might be biased and underestimate the funds' returns. In order to accurately calculate monthly net returns of mutual funds, net asset value (NAV) at the end of the month, NAV at the end of the previous month, dividend payout ratio and the NAV in which dividends are reinvested are taken into account. The formula provided by Morningstar (2007) is given as follows:

$$
R_{i t}=\log _{e}\left[\frac{N A V_{i t}}{N A V_{i t-1}} \times \prod_{j=1}^{m} \text { Ratio }_{j} \times \prod_{i=1}^{n}\left(1+\frac{D_{i}}{N_{i}}\right)\right]
$$

Where $R_{\text {it }}$ represents monthly net returns of fund $\mathrm{i}$ in month $\mathrm{t}, N A V_{i t}$ is the net asset value at the end of month $\mathrm{t}, N A V_{i t-1}$ is the net asset value at the end of month $\mathrm{t}-1, \mathrm{~m}$ is the number of times shares are split within a month, Ratio ${ }_{j}$ is the split ratio on the $j^{\text {th }}$ share split, $\mathrm{n}$ is the number of times cash dividend is paid out, $D_{i}$ is the cash dividend paid out ratio on the $i^{\text {th }}$ cash dividend payout and $N_{i}$ is the net asset value in which dividends are reinvested, under the assumption of zero fees and expenses ${ }^{3}$. 
In order to calculate mutual funds' returns that are gross of managerial expenses and fund custodian fees, all annual expenses and fees are divided by 12 and included in equation (2) as follows:

$$
R_{i t}=\log _{e}\left[\frac{N A V_{i t}+E_{t}}{N A V_{i t-1}} \times \prod_{j=1}^{m} \text { Ratio }_{j} \times \prod_{i=1}^{n}\left(1+\frac{D_{i}}{N_{i}}\right)\right]
$$

Where $R_{i t}$ is the monthly gross return of mutual fund $\mathrm{i}$ in month $\mathrm{t}$, and the only difference between equation (1) and equation (2) is the term $E_{t}$, which is the monthly expense and fee cost. Equation (2) takes into account the managerial expenses and custodian fees at the end of each month, but front- and/or end-loads fees are not considered.

\subsection{Single-index model for mutual funds' risk-adjusted returns}

Single-index alpha (Jensen, 1968) is employed to measure the mutual fund performance as shown in equation (3)

$$
R_{i t}-R_{f t}=\alpha_{i}+\beta_{i}\left(R_{m t}-R_{f t}\right)+\varepsilon_{i t}
$$

Where $R_{i t}$ is the net return (gross return) on the fund $\mathrm{i}$ in month $\mathrm{t}$ calculated from equations (1) and (2), $R_{f t}$ is the risk-free rate in month $t, R_{m t}$ is the return on the local equity benchmark in month $\mathrm{t}$ from A-Share composite index, $\alpha_{i}$ is the intercept term, and $\varepsilon_{i t}$ is the error term.

The single-index alpha (Jensen, 1968) which is the intercept term in equation (3) represents superior (inferior) performance of fund $i$ if the alpha is greater (less) than zero. The regression assumes the error terms are independently and normally distributed with a zero mean and constant variance for all observations. The single-index alpha for each fund is generated from equation (3) as well as the single-index alpha value for the whole sample. The research period for the whole sample starts from July 2004 when the first fund in the sample was established until December 2010. A positive alpha for a fund generated from net returns (or gross returns) indicates that the mutual fund managers have selective ability (or after considering expenses and fees), and a negative alpha indicates they do not have the selective ability. The overall conclusion of whether equity mutual fund managers in China have selective ability to outperform passively managed portfolios will be obtained from the equally-weighted mean of all funds' alphas.

\subsection{Four-index model for mutual funds risk-adjusted returns}

Elton, Gruber and Blake (1996) argue that since mutual funds might have specific investment objectives in specific stock' characteristics such as growth or value, bigcapitalization or small-capitalization, the risk-adjusted alpha would be more accurate after introducing more indexes to account for the markets' performance. The four-index model is shown in equation (4): 
$R_{i t}-R_{f t}=\alpha_{i}+\beta_{i S P}\left(R_{m t}-R_{f t}\right)+\beta_{s} S M B_{t}+\beta_{g v} H M L_{t}-\beta_{b}\left(R_{b t}-R_{f t}\right)+\varepsilon_{i t}$

Where $\alpha_{i}$ is a factor-adjusted alpha for fund $\mathrm{i}, R_{m t}$ is return of S\&P/CITIC Composite A-Share index in the month $\mathrm{t}, S M B_{t}$ is the return of the small-large index in the month $\mathrm{t}, H M L_{t}$ is the difference between returns of growth index and value index. The small-large index is form by large-cap index subtracting small-cap index. Growth index is formed by averaging the large-cap, mid-cap and small-cap stock growth indexes and subtracting the average of the large-cap, mid-cap and small-cap stock value indexes. $R_{b t}$ is the return of bond market index in the month $\mathrm{t}$, and $R_{f t}$ is the risk-free rate.

The four-index alpha of each fund is computed over each fund's history. If the equallyweighted mean of all funds' four-index alpha is positive, the result indicates that equity mutual fund managers in China have selective ability after considering the characteristics of BTM and size in the stock market and bond market influence.

\subsection{Models for market timing measurement}

Treynor and Mazuy (1966) argue that mutual fund managers may hold a higher proportion of the market portfolio if they are able to forecast future market conditions and expect the stock market is a bull market. On the other hand, mutual fund managers may hold lower proportion of the market portfolio if they expect the market will perform poorly in future. Therefore, beta, which is the coefficient of the excess market returns in Jensen's (1968) model (equation 3) will be adjusted according to the returns on the market portfolio as follows if the managers have market timing ability:

$\beta_{i t}=\beta_{i 0}+\beta_{i 1}\left(R_{m t}-R_{f t}\right)$

Substituting the adjusted beta of the mutual fund investment portfolio in equation (5) into equation (3) yields the Treynor and Mazuy (1966) market timing model shown in equation (6):

$R_{i t}-R_{f t}=\alpha_{i}+\beta_{i 0}\left(R_{m t}-R_{f t}\right)+\beta_{i 1}\left(R_{m t}-R_{f t}\right)^{2}+\varepsilon$

Where $\alpha_{i}$ is the timing-adjusted alpha, which represents the timing-adjusted selective ability of mutual fund managers if $\alpha_{i}$ is positive, and a lack of that ability if $\alpha_{i}$ is negative. The quadratic term in equation (6) is the market timing factor and the coefficient of the market timing factor, $\beta_{i 1}$, represents mutual fund managers' market timing ability. If $\beta_{i 1}$ is positive, mutual fund managers have superior market timing ability, which means the investment portfolios of mutual funds are adjusted actively to anticipated changes in market conditions. A negative $\beta_{i 1}$ implies that mutual fund managers do not exhibit market timing ability. 
Henriksson and Merton's (1981) market timing model is also used in this study. In the binary option approach developed by Henriksson and Merton, mutual fund managers are assumed to have the ability to forecast whether the stock market would be better or worse than the risk-free rate. The accurate forecasting of market movements allows mutual fund managers to adjust their investment portfolios' proportions accordingly. By adding a no cost put option into Jensen's (1968) model (equation 3), the Henriksson and Merton (1981) market timing model is shown in equation (7):

$$
R_{i t}-R_{f t}=\alpha_{i}+\beta_{i}\left(R_{m t}-R_{f t}\right)+\gamma_{i} \operatorname{Max}\left(0, R_{f t}-R_{m t}\right)+\varepsilon
$$

The term $\operatorname{Max}\left(0, R_{f t}-R_{m t}\right)$ represents the binary option, and $\gamma_{i}$ indicates mutual fund managers have market timing ability only if $\gamma_{i}$ is positive. The total return of a fund can be represented by the sum of returns from the investment portfolio and the returns of a put option on the stock market, which would be exercised only if the market return is less than the risk-free rate.

Equation (7) can be rewritten as follows:

$$
R_{i t}-R_{f t}=\alpha_{i}+\beta_{i 1}\left(R_{m t}-R_{f t}\right)+\beta_{i 2}\left[D_{t}\left(R_{m t}-R_{f t}\right)\right]+\varepsilon
$$

Where $D_{t}$ is a dummy variable and equals to zero in month $t$ if the market return is greater than the risk-free rate, and equals -1 in month $t$ if market return is less than the risk-free rate. In the other words, $\beta_{i 1}$ is the systematic risk estimator when the stock market is booming and $\left(\beta_{i 1}-\beta_{i 2}\right)$ is the fund's beta when the stock market crashes. The intercept, $\alpha_{i}$, represents the timing-adjusted selective ability of mutual fund managers if $\alpha_{i}$ is positive, and mutual fund managers do not have selective ability if $\alpha_{i}$ is negative. A positive $\beta_{i 2}$ indicates mutual fund managers have superior market timing ability and a negative $\beta_{i 2}$ shows mutual fund managers have inferior market timing ability.

\section{Research Findings}

\subsection{Equity mutual fund managers' selective ability based on single-index model using mutual funds net returns}

This study used Jensen's (1968) method to measure mutual fund performance to test managers' selective ability. Monthly net returns of each fund, after deducting expenses and fees, are compared with the monthly returns of the S\&P/CITIC composite A-share index from the month that the fund was first established to December 2010. The intercept term $\left(\alpha_{i}\right)$ of the single-index model in equation (3) represents the excess returns of each fund in the sample. According to Jensen (1968), mutual fund managers might have selective ability only if a mutual fund has a superior performance (positive excess return) and the positive single-index alpha is greater than zero.

Table 1 shows the summary statistics of the regression estimates of the parameters of equation (3) based on net returns for all 149 equity funds in the sample from 2004 to 2010. 
The average risk-adjusted excess net return (alpha) of the 149 equity mutual funds in China is $0.857 \%$ per month from 2004 to 2010 , which indicates that Chinese equity mutual funds can earn up to $10.786 \%$ excess returns per year over the CITIC/S\&P composite A-share index.

\begin{tabular}{|l|l|l|}
\hline Table $\mathbf{1}$ & $\begin{array}{l}\text { Summary Statistics of Mutual Funds Net Returns Using the Single-Index } \\
\text { Model (2004-2010) }\end{array}$ \\
\hline Variable & Coefficient & t-statistics \\
\hline Alpha & 0.008572 & $2.897735^{* * *}$ \\
\hline Beta & 0.703876 & $25.2806^{* * *}$ \\
\hline
\end{tabular}

Note: $* * *$ Significant at $1 \%$ level.

The superior performance, represented by the positive single-index alpha in equation (3) is greater than zero at $1 \%$ level of significance. The most successful fund could earn $0.276 \%$ excess returns per month, the worst fund exhibited a negative performance of $0.122 \%$ per month, and the median value of excess returns in the sample is $0.0446 \%$ per month. The average beta is 0.697 with a maximum value of 0.965 and a minimum value of 0.349 . The systematic risk portfolios of the mutual funds is less than the market portfolio systematic equity risk in China.

The estimated single-index alpha is consistent with the studies of McDonald (1974), Carlson (1970), Mains (1977), and Ippolito (1989). Mains's study (1977) which documented a positive alpha based on net returns of $0.09 \%$ per year. Carlson's (1970) study showed a positive alpha with a value of $0.6 \%$ per year and Ippolito (1989) showed an alpha of $0.81 \%$ per year. Consistent with previous researches, the single-index alpha based on the mutual funds net returns in this study is also positive with a value of $0.857 \%$ per month and is statistically significant at the $1 \%$ level. The result indicates that, on average, the funds could earn about $0.857 \%$ more per month (equivalent to $10.786 \%$ per year) than they could have earned given their level of systematic risk (Jensen, 1968). Therefore, based on the positive alpha generated from the mutual funds net returns, equity mutual fund managers in China have selective ability to earn excess returns.

The beta coefficient of 0.697 is less than 1 and is statistically significant at the $1 \%$ level (see Table 1). The result is consistent with Jensen's (1968) study, which produced an average beta of 0.84 . The beta coefficient is less than 1 which indicates that mutual funds, on average, hold less risky portfolios than the market portfolio.

Table 2 and Figure 1 show the frequency distribution of alphas (risk-adjusted excess net return of each fund) during the study period. The data in Table 2 shows 109 funds in the sample earned positive excess net returns, and 40 funds earned negative excess net returns. Figure 1 shows the frequency distribution of the single-index alpha is skewed to the positive side, where most of the mutual funds (approximately 73\%) in the sample recorded positive performance statistically. The result of the frequency distribution of alphas is consistent with Mains's (1977) findings. Over three-fifths of the mutual funds achieved a positive performance using net returns, which confirms that managers have selective ability. Mains's study also shows that the number of funds earning positive excess net returns is more than 
the number of funds earning negative excess net returns. In addition, the frequency distribution of alphas (excess net returns) in Mains's study is also positively skewed.

\begin{tabular}{|c|c|}
\hline Table 2 & \multicolumn{2}{l|}{$\begin{array}{l}\text { Frequency Distribution of the Single -Index Alpha Based on Mutual Funds } \\
\text { Net Returns ( 2004-2010) }\end{array}$} \\
\hline$\alpha>0$ & 109 \\
\hline$\alpha<0$ & 40 \\
\hline Average $\alpha$ & 0.004829 \\
\hline
\end{tabular}

\section{Figure 1 Frequency Distribution of Single-Index Alpha Based on Mutual Funds Net Returns (2004-2010)}

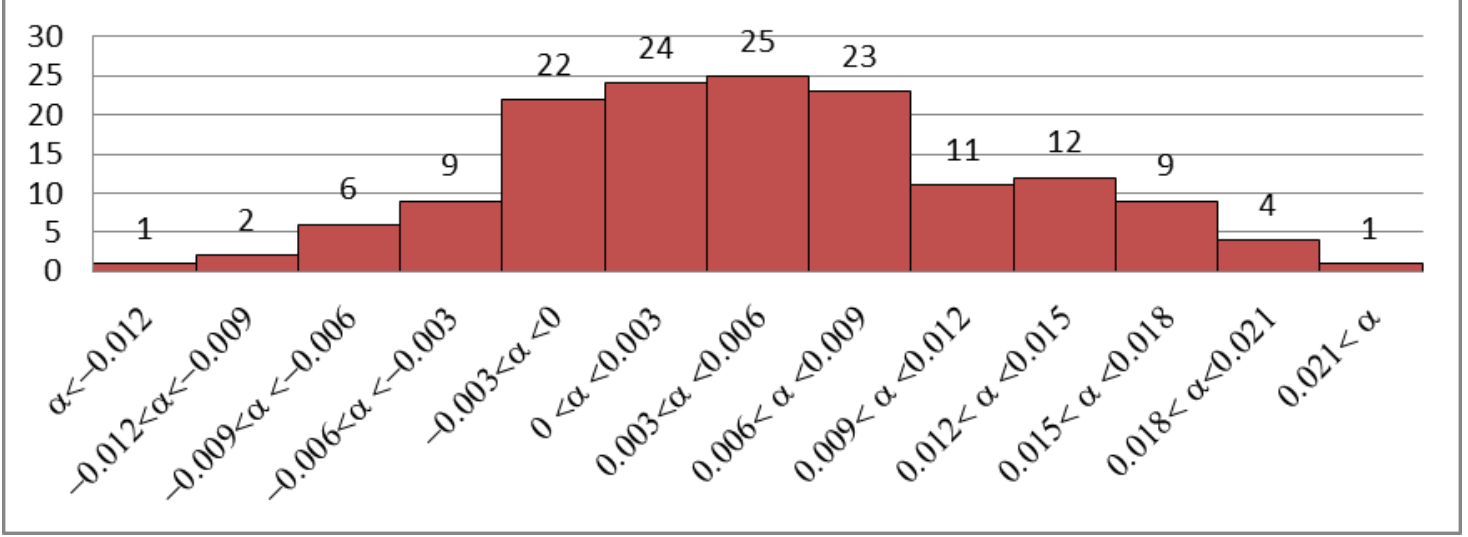

Following the studies of Jensen (1968) and Ippolito (1989), the t-values for each single-index alpha of the equity mutual funds in China are calculated to analyse the statistical significance of the estimated single-index alpha based on net returns. Since the established date of each mutual fund varies, the observation periods and the critical t- values at the $5 \%$ level of significance (one-tail) for each mutual fund are different. The longest and the shortest observation period for this study are 78 and 12 months, respectively. According to the results, the t-values of 31 funds are positive and statistically significant at the $5 \%$ level $^{4}$. The result indicates that $20.8 \%$ of the mutual funds (31 out of 149 ) could earn positive excess returns during the entire study period, thus the managers from these funds may have selective ability. Jensen (1968) argues that if the estimated single-index alpha is zero on average for the whole sample, $5 \%$ of these funds would be expected to yield positive/negative statistically significant results because of random chance. In the other words, if there are more than $5 \%$ of the funds in the sample with positive/negative singleindex alpha, the funds in the sample would earn positive/negative excess returns rather than zero. In this study, $20.8 \%$ mutual funds in the sample could earn positive excess returns, which further indicate that equity mutual funds in China could successfully offset their expenses and the mutual fund managers might have selective ability to earn excess returns.

\subsection{Equity mutual fund managers' selective ability based on the single-index model using mutual funds gross returns}

According to the mutual funds managers selective ability test based on net returns, we conclude that managers might have selective ability only for mutual funds with positive 
excess net returns. However, for mutual funds with negative excess net returns, the managers might also have selective ability. When negative excess net returns result from expense and fees, these mutual funds could still earn non-negative excess net returns if there is no expenses and fees, and therefore are considered to have selective ability (Jensen, 1968).

In order to further test the selective ability of mutual fund managers when considering expenses and fees, gross returns are used to calculate excess gross returns which are employed as the measurement of the mutual funds' performance. As discussed in Section 3.1, gross returns of mutual funds are calculated by adding managerial expense and fees to net returns ${ }^{5}$. Since gross returns are greater than net returns, excess gross return are expected to be relatively greater than excess net return for same mutual fund. For the mutual funds with negative excess net returns, the selective ability of the mutual funds could be identified if the excess gross returns are positive. These funds are just not good enough to recover their expenses and management fees (Jensen, 1968). Therefore, the number of mutual fund managers, who might have selective ability based on gross returns, should be no less than the number shown based on net returns.

Similar to the previous test based on net returns, monthly funds gross returns (after considering expenses and fees) are compared with monthly returns of the S\&P/CITIC composite A-share index from the month the fund was established until December 2010. If positive excess gross returns (alpha is greater than zero) could be earned by a mutual fund, the manager might have selective ability (Jensen, 1968).

Table 3 presents the summary statistics and estimated intercepts based on gross returns from equation (3) for all 149 equity funds in the sample. An excess gross return (alpha) of $0.972 \%$ per month could be earned on average for all the 149 funds, which is equivalent to $12.31 \%$ per year. The t-value of the coefficient of alpha is positive and statistically significant at the $1 \%$ level. The result suggests that mutual fund managers might have selective ability after considering expenses and fees (, which is consistent with Mains's (1977) findings. Comparing the results based on net returns and gross returns, the average excess gross returns $(0.972 \%)$ are higher than the excess net returns, $(0.857 \%)$, which is consistent with Jensen's (1968) result. Since the gross returns equal the subtotal of net returns plus fees and expenses, it is expected that the excess gross returns are larger than the excess net returns. Similarly, Mains (1977) finds mutual funds, on average, could earn excess gross returns of $1.07 \%$ per year (excess net returns are $0.09 \%$ per year).

\begin{tabular}{|l|l|l|}
\hline Table 3 & \multicolumn{3}{l|}{$\begin{array}{l}\text { Summary Statistics of Mutual Funds Gross Returns Using the Single-Index } \\
\text { Model (2004-2010) }\end{array}$} \\
\hline Variable & Coefficient & t-statistics \\
\hline Alpha & 0.0097 & $2.9834^{* * *}$ \\
\hline Beta & 0.7879 & $25.6731^{* * *}$ \\
\hline
\end{tabular}

Note: $* * *$ Significant at $1 \%$ level.

Table 4 and Figure 2 show the frequency distribution of the single-index alpha (excess gross returns of each fund during the study period). The result shows that 121 of the 149 funds earned positive excess gross returns and 28 funds earned negative excess gross returns. 
Approximately $81 \%$ of the funds in the sample performed better than the passively managed portfolio after considering expenses and fees.

\begin{tabular}{|c|c|}
\hline Table 4 & $\begin{array}{l}\text { Frequency Distribution of the Single -Index Alpha Based on Mutual Funds } \\
\text { Gross Returns (2004-2010) }\end{array}$ \\
\hline$\alpha>0$ & 121 \\
\hline$\alpha<0$ & 28 \\
\hline Average $\alpha$ & 0.006264 \\
\hline
\end{tabular}

\section{Figure 2 Frequency Distribution of Single-Index Alpha Based on Mutual Funds Gross Returns (2004-2010)}

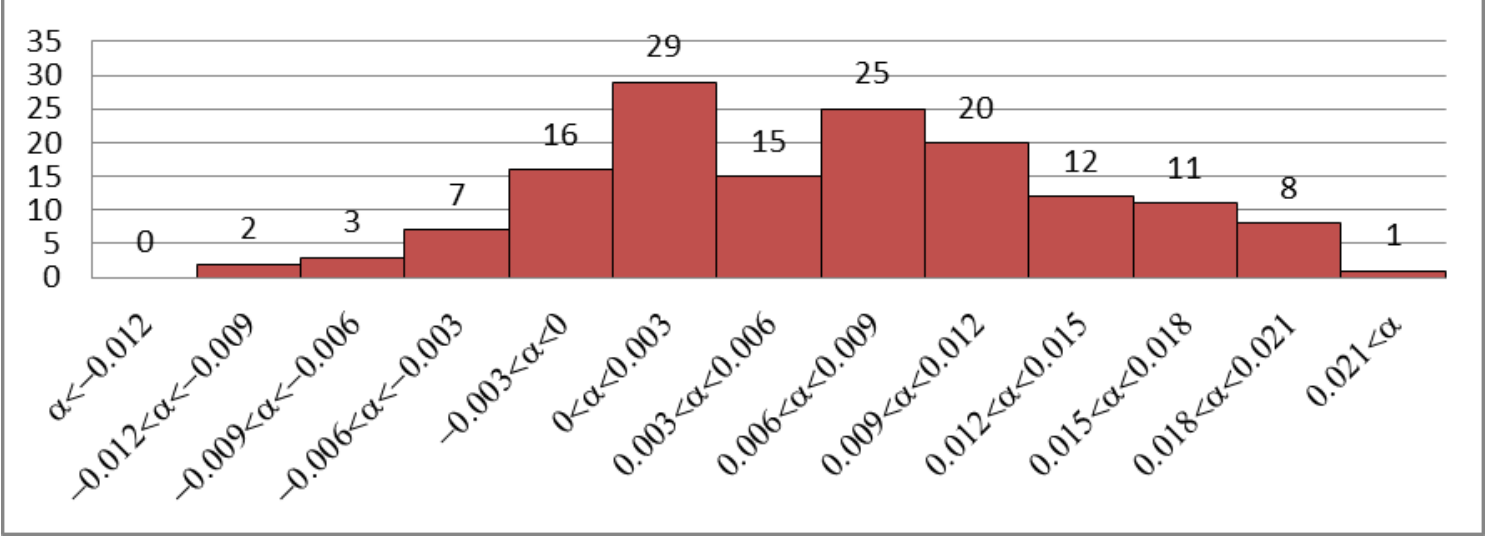

The results in Table 4 and Figure 2 show most mutual funds in the sample generated a superior performance than the selected market index, and mutual fund managers might have selective ability. There are only 28 funds in the sample with negative excess gross returns, which indicates managers from these funds performed worse than the selected market index and might not have selective ability.

According to the results shown in Table 4, the number of mutual funds with positive excess gross returns (121) is greater than the number of mutual funds with positive excess net returns (109) (see Table 2) which is consistent with Jensen's (1968) study. In addition, the frequency distribution of the single-index alpha shown in Figure 2 is skewed more towards the positive compared with the results in Figure 1 which is also consistent with Jensen's (1968) study. The difference between the number of mutual funds with positive excess gross returns (121) and positive excess net returns (109) is 12. According to Jensen (1968), the increasing number of mutual funds with positive excess returns (12 mutual funds in the sample) implies that those mutual fund managers might have selective ability but are not good enough to fully offset the fees and expense.

Similarly with the test based on net returns, the t-values are generated to further analyse the statistical significance of the estimated single-index alpha based on gross returns. The results show that the t-values of 40 of the 149 mutual funds show the single-index alpha is statistically significant at the $5 \%$ level $^{6}$. The result also indicates $26.85 \%$ of the mutual funds (40 of 149) in the sample could earn positive excess gross returns during the entire study period, which confirms that the managers from these mutual funds might have selective ability. 


\subsection{Equity mutual fund managers' selective ability based on the four-Index model}

The Elton, Gruber and Blake (1996) four-index model is employed in this study to test mutual fund managers selective ability after considering the characteristics of book-tomarket ratio, size in stock market and bond market influences (see equation 4). The intercept term, $\alpha_{i}$ represents the risk-adjusted excess returns after considering the stocks' characteristic factors using mutual funds net returns.

Table 5 presents the estimated parameters in equation (4). The four-index alpha, generated from the Elton, et al. (1996) four-index model is $0.846 \%$, and is statistically significant at the $1 \%$ significant level. The result indicates that equity mutual funds in China could earn $0.846 \%$ excess net returns per month (10.46\% per year) on average after considering stock characteristics such as Book-to-Market factor (BTM), size factor (SMB) and bond market effects.

\begin{tabular}{|l|l|l|}
\hline Table 5 & \multicolumn{3}{l|}{$\begin{array}{l}\text { Summary Statistics of Mutual Funds Net Returns Using the Four- } \\
\text { Index Model (2004-2010) }\end{array}$} \\
\hline Variable & Coefficient & t-statistics \\
\hline Alpha & 0.008462 & $3.670873 * * *$ \\
\hline Beta & 0.734099 & $29.77938 * * *$ \\
\hline HML & 0.078833 & $3.093918^{* * *}$ \\
\hline SMB & -0.236115 & $-5.891183^{* * *}$ \\
\hline Bond & 0.178686 & 0.470558 \\
\hline
\end{tabular}

Note: $* * *$ Significant at $1 \%$ level.

In addition, the positive significant four-index alpha generated from the four-index model is consistent with the results from the single-index model (Jensen model) described in section 4.1 and 4.2. The results further show that mutual fund managers in China might have selective ability after considering the stock characteristics such as book-to-market ratio, size in stock market and bond market influence.

Table 5 show the coefficient of the BTM is positive and significant at the $1 \%$ level, whereas the coefficient of the size factor (SMB) is negative and significant at the $1 \%$ level. Therefore, a negative correlation between BTM and SMB is identified. However, the coefficient of the bond effect is negative but insignificant.

These results are consistent with Fletcher and Marshall's (2005) study, that employed Elton et al.'s (1996) model and found a positive coefficient of BTM, negative coefficient of the SMB factor and an insignificant result of the bond effect in the U.K. stock market. The negative relationship between book-to-market and size effect is also consistent with Bauer, Guenster and Otten's (2004) study. According to Fama and French (1993), a positive BTM indicates mutual fund investor prefer to invest in value stocks, and a negative SMB suggests mutual funds prefer to invest in large-cap stocks ${ }^{7}$. 
The results in Table 5 suggest that the investment style for mutual funds in China favours large-cap and value portfolios. Furthermore, because of the insignificant coefficient of the bond effect, investing in the bond market is possibly not a common strategy for hedging for mutual fund managers in China.

\subsection{Results of market timing ability}

The Treynor and Mazuy (1966) and Henriksson and Merton (1981) market timing models are used to test market timing ability of equity mutual fund managers in China (see equations (6) and (8)). In Treynor and Mazuy's (1966) model, the coefficient of the quadratic term measures the market timing ability. A positive coefficient of the quadratic term in Treynor and Mazuy's model indicates mutual fund managers might have market timing ability. A positive coefficient of the binary term in Henriksson and Merton's (1981) model shows mutual fund managers have market timing ability.

\subsubsection{Market timing ability based on Treynor and Mazuy's (1966) model}

Table 6 presents the coefficients of the estimated parameters in equation (6). Both net and gross returns of mutual funds in the sample are regressed to calculate the excess returns $(\alpha)$ and the indicators for market timing ability $\left(\beta_{i}\right)$. The positive result of alpha (1\% for net returns and $1.2 \%$ for gross returns per month) shows mutual funds could earn excess returns on average based on net and gross returns. In addition, the t-value for excess net and excess gross returns, 2.74 and 3.53, respectively, are statistically significant at the $1 \%$ level. The results are consistent with the results from the single-index model (Jensen, 1968) and further confirm that mutual fund managers have selective ability. The coefficients of the quadratic term $\left(\beta_{i 1}\right)$, based on the net and gross returns, are -0.124 (statistically insignificant) and -0.254 (statistically significant at $10 \%$ level), respectively. According to Treynor and Mazuy (1966), only a significant positive $\beta_{i 1}$ indicates that mutual fund managers have market timing ability to forecast market conditions, and then adjust their portfolio to earn excess returns.

\begin{tabular}{|c|l|l|c|l|l|}
\hline Table 6 & $\begin{array}{l}\text { Summary Statistics of Treynor and Mazuy (1966) Market Timing Model } \\
(2004 \text { to 2010) }\end{array}$ \\
\hline Net Returns \\
\hline Variable & Coefficient & t-Statistic & Variable & Coefficient & t-Statistic \\
\hline$\alpha$ & 0.01004 & $2.739694^{* * *}$ & $\alpha$ & 0.012721 & $3.529845^{* * *}$ \\
\hline$\beta$ & 0.698989 & $24.23538^{* * *}$ & $\beta$ & 0.777889 & $23.05424 * * *$ \\
\hline$\beta_{i 1}$ & -0.124332 & -0.683217 & $\beta_{i 1}$ & -0.253503 & $-1.367467^{*}$ \\
\hline
\end{tabular}

Note: $* * *$ Significant at $1 \%$ level.

* Significant at $10 \%$ level.

Based on Treynor and Mazuy's (1966) model, our result shows none of the indicators $\left(\beta_{i 1}\right)$ for market timing ability based on the net and gross returns are significantly positive, which indicates that equity mutual fund managers, on average, in China do not have market timing ability. The result is consistent with Treynor and Mazuy (1966) and Cumby and Glen (1990) 
in the U.S. stock market and Abdel-Kader and Kuang (2007) in Hong Kong stock market. There is no evidence of market timing ability for equity mutual funds in China. Therefore, the positive excess returns earned by Chinese equity mutual funds could be the result of selective ability of mutual fund managers not the market timing ability.

\subsubsection{Market timing ability based on Henriksson and Merton's (1981) model}

Table 7 summarises the coefficients of the estimated parameters in equation (8). The excess returns $(\alpha)$ of $1.13 \%$ and $1.5 \%$, generated by net and gross returns, respectively, are statistically significant at the $5 \%$ level. Similarly, the results of significant positive excess returns indicate that mutual fund managers have selective ability, and are consistent with the results in the Jensen (1968) and Treynor and Mazuy (1966) models.

\begin{tabular}{|c|l|l|c|l|l|}
\hline Table 7 & $\begin{array}{l}\text { Summary Statistics of Henriksson and Merton (1981) } \\
\text { (2004 to 2010) }\end{array}$ \\
\hline Net Return & \multicolumn{5}{l|}{ Gross Ret Timing Model } \\
\hline Variable & Coefficient & t-Statistic & Variable & Coefficient & t-Statistic \\
\hline$\alpha$ & 0.011382 & $3.013539^{* * *}$ & $\alpha$ & 0.015064 & $3.640279^{* * *}$ \\
\hline$\beta$ & 0.668255 & $14.21703^{* * *}$ & $\beta$ & 0.720217 & $14.16514^{* * *}$ \\
\hline$\gamma_{i}$ & -0.06594 & -0.827482 & $\gamma_{i}$ & -0.125205 & -1.376888 \\
\hline
\end{tabular}

Note: $* * *$ Significant at $1 \%$ level.

The coefficient of the binary option term in equation (8), $\gamma_{i}$, shows negative results of -0.066 and -0.125 , for the net and gross returns, respectively. The negative values of $\gamma_{i}$ are statistically insignificant. According to Henriksson (1984) and Henriksson and Merton (1981), insignificant values of $\gamma_{i}$ show inferior market timing ability; i.e., mutual fund managers are unable to outguess the market conditions and change their portfolio proportions accordingly. Consistent with Henriksson (1984), Chang and Lewellen (1984), Kao, Cheng and Chan (1998), Bangassa (1999), Connor and Korajczyk (1991) and Hallahan and Faff (1999) studies, the result from Henriksson and Merton (1981) model provides no evidence of mutual fund managers having market timing ability.

\section{Conclusion}

The results from this study reveal that the equity mutual fund managers in China have selective ability to earn excess returns, but do not have market timing ability. The results from the single-index model based on net and gross returns confirm the findings from previous studies (Mains, 1977; McDonald, 1974; Carlson, 1970; and Ippolito, 1989), which suggest equity mutual fund managers in China might have selective ability to pick up underpriced stocks and/or sell overvalue stocks to earn excess returns. The result of selective ability is also confirmed by the four-index model, which further suggests that the positive excess returns earned are further explained by investing in large-cap and/or value stocks by equity mutual fund managers in China. The result further suggests that mutual funds in China are sufficiently successful in finding and implementing new information to offset their expenses in research and trading activities. On the other hand, the results of the 
market timing factors from two market timing models (Treynor and Mazuy, 1966 and Henriksson and Merton, 1981) are negative and statistically insignificant. The results are consistent with prior studies ${ }^{8}$, and suggest that equity mutual fund managers in China do not have market timing ability, which further indicate that mutual funds manager could possess good selectivity and overall performance, but are unable to outguess the market conditions and change their portfolio proportion accordingly.

There are certain limitations in this study. The first limitation is the relatively small sample size and short research period compared to studies documented in the US. Since mutual funds are new to the market in China, the first open-end fund was issued in 2001 and the first equity mutual fund was established in 2004. The second limitation is the scope of this study, which focuses only on equity mutual funds in China. Due to the difficulties in obtaining relevant data and constructing appropriate benchmark indices, other types of funds, such as balanced funds and debt funds in China, are not included in this study. Therefore, the empirical methods in this study are applied only to test performance for equity mutual funds, and the conclusions reached in this study cannot be applied to the entire mutual funds industry in China.

Another limitation of this study is the benchmark indices selection. The benchmark applied in this study is the S\&P/CITIC indices, however, not all mutual fund managers use the $\mathrm{S} \& \mathrm{P} / \mathrm{CITIC}$ indices as the benchmark. This is because there are other market index available (such as Shanghai A-share market index, Shenzhen A-share market index and ShanghaiShenzhen $\mathbf{3 0 0}$ market index) for mutual fund managers to choose, but none of the index is an official overall market index for both Shanghai and Shenzhen A share markets in China. $\mathrm{S} \& \mathrm{P} / \mathrm{CITIC}$ is the best benchmark available for this study since it is the only overall market index available in China. If an overall official market index is available in China in the future, mutual fund managers, who currently choose official indices or S\&P/CITIC, could switch to the overall official market index. As a result, the overall official market index, which is not available at the moment, could become a better benchmark than S\&P/CITIC to evaluate mutual funds' performance in China.

Future research could conduct tests for other types of funds, such as debt funds, balanced funds, index funds and QFIls, and compare the managers' selective ability among different types of mutual funds. Testing the selective ability and market timing ability of all types of mutual funds could provide an overview of mutual fund industry in China. In addition, which types of mutual funds in China perform better could be examined by comparing the selective ability among different types of mutual funds. Future research could also compare mutual fund managers' selective ability between foreign mutual funds (QFIls) and other domestic mutual funds in China (such as equity funds, debt funds, balance funds, and index funds) to test whether managers from domestic mutual funds have better selective ability than managers from foreign financial institutions (QFIls). 


\section{References}

Alexander, G.J, and Stover, R. (1980).Consistency of mutual fund performance during varying market conditions. Journal of Economics and Business, 32, 219-226.

Abdel-Kader, M., and Kuang, Y. (2007). Risk-Adjusted Performance, Selectivity, Timing Ability and Performance Persistence of Hong Kong Mutual Funds. Journal of Asia-Pacific Business, Vol. 8, No. 2, pp. 25-58.

Bangassa, K. (1999). Performance of UK investment Trusts: 1980-1994. Journal of Business Finance and Accounting, Vol. 26. Issue 9-10, pp. 1141-1168.

Bauer, R., Guenster, N., and Otten, R. (2004). Empirical evidence on corporate governance in Europe: The effect on stock returns, firm value and performance. Journal of Asset Management, Vol. 5, pp. 91-104.

Carlson, R. (1970). Aggregate Performance of Mutual Funds, 1948-1967.The Journal of Financial and Quantitative Analysis, Vol. 5, No. 1, pp. 1-32.

Chang, E., and Lewellen, W. (1984). Market timing and mutual funds investment performance. Journal of Business, 57, 52-72.

Connor, G., and Korajczyk, R.A. (1991).The attributes, behaviour, and performance of U.S. mutual funds. .Review of Quantitative Finance and Accounting, Vol. 1, No. 1, pp. 5-26.

Cumby, R.E., and Glen, J.D. (1990). Evaluating the Performance of International Mutual Funds. Journal of Finance, June, pp. 497-521

Drew, M. E., Naughton, T., and Veeraraghavan, M. (2003). Firm size, book-to-market equity and security returns: evidence from the Shanghai stock exchange. Australian Journal of Management, 28(2), 119-139.

Elton, E.J., Gruber, M.J., and Blake, C.R. (1996).The persistence of risk-adjusted mutual fund performance. The Journal of Business, Vol.69, No.2, pp. 133-157 .

Fama, E. F. (1970). Efficient capital markets: A review of theory and empirical work. Journal of Finance, 25, 383-417.

Fama, E. F. (1972). Components of investment performance. Journal of Finance. 27. pp. 55167.

Fama, E. F., and French, K. R. (1993). Common risk factors in the returns on stocks and bonds, Journal of Financial Economics. Issue 33, pp. 3-56.

Fletcher, J., and Marshall, A. (2005). The performance of UK international unit trusts. European Financial Management, Vol.11, Issue.3, pp.365-386.

Gallo, J.G., and Lockwood, L.J. (1999). Fund management changes and equity style shifts. Financial Analysts Journal, Vol.55, No.5, pp.44-52.

Gallo, J. G., and Swanson, P. E. (1996). Comparative measures of performance for U.S. based international equity mutual funds. Journal of Banking \& Finance, Vol.20, 16361650.

Grinblatt, M., and Titman, S. (1989). Mutual fund performance: An analysis of quarterly portfolio holdings. Journal of Business, 62, 393-416.

Grinblatt, M., and Titman, S. (1993). Performance measurement without benchmarks: An examination of mutual fund returns. The Journal of Business, Vol. 66, No.1, pp. 47-68.

Goetzmann, W., and Ibbotson, R. (1994). Do winners repeat? Patterns in mutual fund performance. Journal of Portfolio Management, 20, 9-18.

Henriksson, R. (1984). Market timing and mutual fund performance: An empirical investigation. Journal of Business, Vol.57, 73-97. 
Henriksson, R., and Merton, R. (1981).On market timing and investment performance. II. Statistical procedures for evaluating forecasting skills. Journal of Business, Vol.54, No.4, pp.513-533.

Hallahan, T. A., and Faff, R. W. (1999). An examination of Australian equity trusts for selectivity and market timing performance. Journal of Multinational Financial Management, Vol. 9, Issue 3-4, pp. 387-402.

Ippolito, R. (1989). Efficiency with costly information: A study of mutual fund performance, 1965-1984. Quarterly Journal of Economics, 104, 1-23

Ippolito, R. (1993). On studies of mutual fund performance. 1962 - 1991. Financial Analysts Journal, 49, 1, 42-50.

Jensen, M. C. (1968). The performance of mutual funds in the period 1945-1964.Journal of Finance, 23, 389-416.

Jensen, M. C. (1972). Optimal utilization of market forecasts and the evaluation of investment portfolio performance. In G. Szego and K. Shell (eds.), Mathematical Methods in Investment and Finance. Amsterdam: North Holland.

Jiang, G.J., Yao, T., and Yu, T. (2007). Do mutual funds time the market? Evidence from portfolio holdings. Journal of Financial Economics, Vol.86, Issue 3, pp.724-758.

Kao, G. W., Cheng. L. T. W., and Chan, K. C. (1998). International mutual fund selectivity and market timing during up and down market conditions. Financial Review, Vol. 33, Issue 2, pp. 127-144.

Kon, S. (1983).The market-timing performance of mutual fund managers. Journal of Business, 56, $323-347$.

Mains, N.E. (1977). Risk, the pricing of capital assets, and the evaluation of investment portfolios: Comment. Chicago Journal, Vol.50, No.3, pp.381-384.

Malkiel, B. G. (1995). Returns from investing in equity funds: 1971-1991. Journal of Finance, 50, 549-72.

McDonald, J.G. (1974). Objectives and performance of mutual funds, 1960 -1969. Journal of Financial and Quantitative, Vol.9, Issue.3, pp. 311-333.

Sharpe, W. (1966).Mutual fund performance. Journal of Business, 39, 119-138.

Treynor, J. L., and Black, F. (1973). How to use security analysis to improve portfolio selection. Journal of Business, Vol.46, No.1, pp. 66-86.

Veit, E. T., and Cheney, J. (1982). Are mutual funds market timers? Journal of Portfolio Management, winter. pp. 35-42.

Treynor, J.L., and Mazuy, K.K. (1966). Can mutual funds outguess the market? Harvard Business Review, July-August, pp.131-136. 


\section{Footnotes}

${ }^{1}$ See http://www.ccerdata.com/eng/AboutUs/About_Us.htm for more details.

${ }^{2}$ This study uses 11 indices including S\&P/CITIC A-share Composite index, S\&P/CITIC Composite Bond index, S\&P/CITIC 100 Index, S\&P/CITIC 200 Index, S\&P/CITIC Small-Cap index and S\&P/CITIC Pure Style indices (pure growth and pure value indices) of S\&P/CITIC 100/200/Small-Cap indices.

${ }^{3}$ Most studies obtain quarterly or monthly return data for mutual funds in the U.S. from CDA, Lipper and Morningstar. Researchers calculate monthly returns for mutual funds only if the data source is provided by Wiesenberger (for example, Bollen and Busse (2005)). Elton, Gruber and Blake (1996) and Cai, Chan and Yamada (1997) describe the process of calculating monthly returns but did not provide the formula to calculate raw return of mutual funds. Equation (1) is obtained from Morningstar (2007) mutual fund performance calculation. It assumes dividends are reinvested at NAV on the same day when dividends are paid out. It might be more accurate if a fund pays out dividends several times in a month. It also considers the effect of share splitting. Many funds split shares and pay out dividend at same time, and then the NAV is adjusted.

${ }^{4}$ The positive excess net returns from 11 out of 149 (approximately 7.4\%) mutual funds and 56 out of 149 (approximately $37.6 \%$ ) mutual funds in the sample are statistically significant at $1 \%$ level and $10 \%$ level, respectively. Following Jensen's study (1968), only the results at $5 \%$ level are reported in this study.

${ }^{5}$ The managerial expense and fees are greater than zero, which are deducted and reflected in Net Asset Value (NAV) of a mutual fund (see equation 2).

${ }^{6}$ The results of positive excess gross returns from 17 out of 149 (approximately 11.4\%) mutual funds and 62 out of 149 (approximately 41.6\%) mutual funds in the sample are statistically significant at $1 \%$ level and $10 \%$ level, respectively.

${ }^{7}$ Based on the results, we can conclude that mutual funds in China can gain positive excess return from investing in value and large-cap stocks. However, they may also invest in growth and small-cap stocks.

${ }^{8}$ See Treynor and Mazuy(1966), Chang and Lewellen(1984),Henriksson(1984), Cumby and Glen(1990), Kao, Cheng and Chan(1998),Hallan and Faff (1999) and Abdel-Kador and Kuang(2007). 